\title{
NILAI RUANG SEBAGAI PEMBENTUK LAPISAN-LAPISAN RUANG DI KAWASAN PATHOK NEGARA DONGKELAN, YOGYAKARTA
}

\author{
*Lutfi Setianingrum¹, Sudaryono², M. Sani Roychansyah ${ }^{2}$ \\ ${ }^{1}$ Jurusan Teknologi Infrastuktur dan Kewilayahan/Program Studi Perencanaan Wilayah dan Kota, Institut Teknologi Sumatera \\ 2Departemen Arsitektur dan Perencanaan/Program Studi Perencanaan Wilayah dan Kota, Universitas Gadjah Mada \\ *lutfisetianingrum@pwk.itera.ac.id
}

\begin{tabular}{l} 
INFO ARTIKEL \\
\hline Riwayat Artikel: \\
Diterima: $17-06-2018$ \\
Disetujui: 20-07-2018 \\
\hline
\end{tabular}

\section{Kata Kunci:}

Masjid Pathok Negara;

Yogyakarta;

Keistimewaan;

Tata ruang lokal;

Nilai lokal;

\begin{abstract}
ABSTRAK
Abstrak: Paper ini menjabarkan pelapisan-pelapisan ruang yang terbentuk di Dongkelan Kauman, sebagai salah satu Kawasan Pathok Negara Yogyakarta. Pelapisan ruang tersebut terbentuk karena adanya nilai ruang yang tertanam kuat dalam pikiran masyarakat lokal Dongkelan Kauman. Pelapisan ruang Dongkelan Kauman terbentuk dalam dua level, yaitu: a) level kampung dan b) level padukuhan. Pada level kampung terdapat tiga lapisan ruang, yaitu: a) teritori ruang; b) radius keunikan; dan c) ruang periferi; sementara pada tingkat padukuhan, lapisan ruang terdiri dari: a) ruang inti dan b) ruang periferi.

Abstract: This paper describes the layering of spaces formed at the Dongkelan Kauman settlements, as the one of Pathok Negara District of Yogyakarta. Those layers are formed by the value of space that is still deeply embedded in the minds of local people. It is formed in two levels, namely: a) kampong level and b) padukuhan level. There are three layers of space formed in the kampong, those are: a) spatial territory; b) radius of uniqueness; and c) spatial periphery; while at the padukuhan level, the layer of space consists of: a) core space and b) spatial periphery.
\end{abstract}

\section{A. LATAR BELAKANG}

Kawasan Pathok Negara Dongkelan, yang sebenarnya bernama Dongkelan Kauman, merupakan salah satu ruang unik di Yogyakarta. Dongkelan Kauman adalah sebuah kampung yang terletak di Kecamatan Kasihan, Kabupaten Bantul, Daerah Istimewa Yogyakarta. Kampung ini disebut sebagai Kawasan Pathok Negara Dongkelan karena disana berdiri salah satu masjid bersejarah Yogyakarta yaitu Masjid Pathok Negara Dongkelan. Kawasan ini telah ditetapkan sebagai salah satu pilar Keistimewaan Yogyakarta melalui Peraturan Daerah Istimewa (Perdais) Daerah Istimewa Yogyakarta nomor 1 tahun 2013.

Kawasan Pathok Negara adalah kawasan tempat berdirinya Masjid-Masjid Pathok Negara Yogyakarta. Kawasan ini merupakan perwujudan spasial dari konsep pathok negara [5] dan telah ditetapkan sebagai pilar keistimewaan Yogyakarta.

Kawasan Pathok Negara merupakan kampung yang telah didirikan sejak lama, namun tetap bertahan hidup sampai saat ini. Keunikan Kawasan Pathok Negara tidak hanya terletak pada fisik spasialnya, melainkan juga pada dinamika sosial kemasyarakatannya. Keunikan tersebut tetap terjaga hingga saat ini, sehingga Rahmi menyebut kawasan Pathok Negara sebagai cultural heritage [6].

Mendetailkan pernyataan Rahmi, Setianingrum dkk mengemukakan bahwa terdapat tiga objek penting di
Kawasan Pathok Negara Dongkelan, yaitu: a) Masjid Pathok Negara; b) pasareyan; dan c) kauman. Ketiga objek tersebut dinyatakan sebagai inti dan identitas dari Dongkelan Kauman sebagai Kawasan Pathok Negara [7].

Paper ini melanjutkan temuan Setianingrum dkk tentang inti dari Dongkelan Kauman. Jika Dongkelan Kauman memiliki inti, maka ia juga memiliki periferi. Paper ini menjabarkan periferi dari inti ruang Dongkelan Kauman yang ternyata terbentuk menjadi beberapa lapisan. Konsep tentang lapisan-lapisan daerah periferi ini kemudian disebut sebagai pelapisan ruang Dongkelan Kauman.

\section{B. METODE PENELITIAN}

\section{Telaah Teoritik}

Kawasan Pathok Negara Dongkelan merupakan kawasan bersejarah Yogyakarta yang telah ada sejak tahun 1775. Kawasan ini telah melewati berbagai masa dan Rahmi tetap mengatakan bahwa kawasan ini adalah kawasan yang unik [6]. Pada setiap tempat yang telah mengalami perjalanan waktu, ada objek yang mengalami perubahan mengikuti perubahan waktu, namun ada pula objek yang tidak mengalami perubahan. Fenomena ini disebut Rossi sebagai konsep continuity and change; kemenerusan dan perubahan [2]

Adanya kemenerusan objek dalam ruang tersebut menimbulkan keterikatan nilai [4] dan memori [3] [1] 
terhadap ruang, sehingga objek tersebut dipandang sebagai objek unik oleh masyarakatnya. Keterikatan antara objek, masyarakat, dan sistem nilai dalam ruang inilah yang disebut Sudaryono sebagai eksistensi spasial. Selain itu objek unik juga dipandang sebagai objek individu yang dapat mempengaruhi ruang sekitarnya. Konsep ruang yang terpengaruh oleh objek unik ini disebut sebagai konsep radius keunikan [4].

Karena keberadaan Masjid Pathok Negara Dongkelan di kawasan tersebut masih dapat diamati sampai saat ini, Kawasan Pathok Negara Dongkelan menunjukkan gejala kemenerusan sebuah objek dalam ruang. Gejala ini direspon oleh Setianingrum dkk dengan mengungkap inti dan identitas ruang Dongkelan Kauman sebagai Kawasan Pathok Negara Dongkelan serta menunjukkan indikasi adanya lapisanlapisan ruang yang terbentuk disana [7].

\section{Metode Penelitian}

Metode penelitian yang digunakan dalam penelitian untuk menulis paper ini adalah metode induktif-fenomenologi. Metode tersebut dipilih karena, sebagai lokus penelitian, Kawasan Pathok Negara Dongkelan merupakan kawasan unik. Metode inilah yang dianggap cocok untuk menggali keunikankeunikan Dongkelan Kauman sebagai Kawasan Masjid Pathok Negara Dongkelan.

\section{Dongkelan Kauman sebagai Lokus Penelitian}

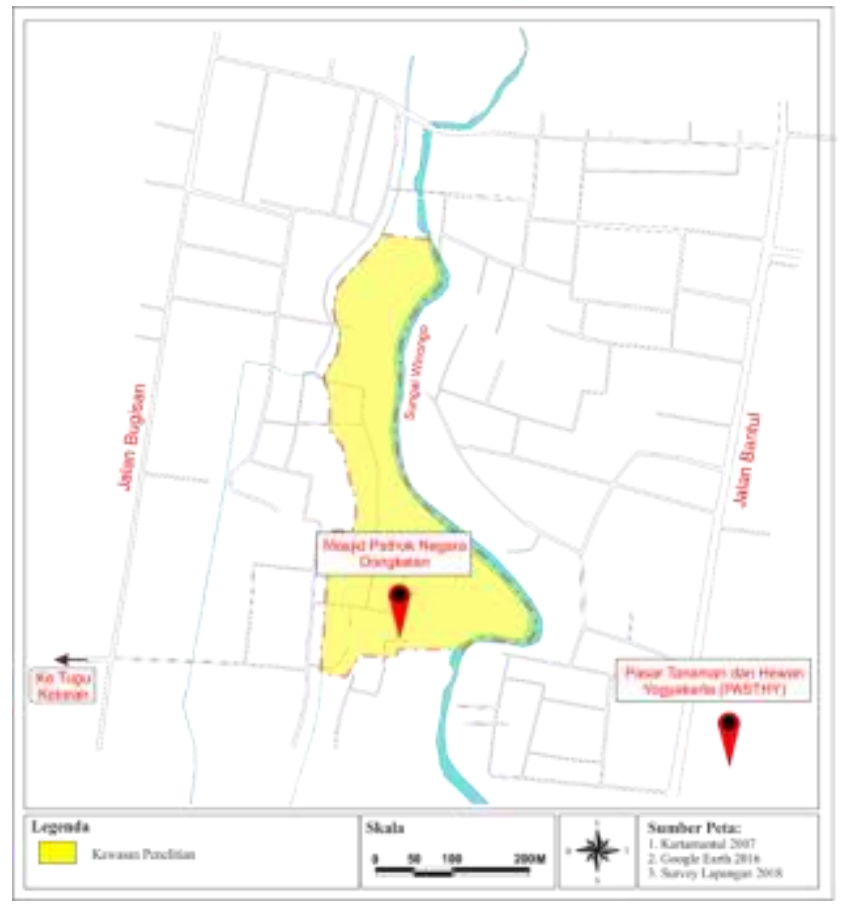

Gambar 1. Peta Letak Dongkelan Kauman

Dongkelan Kauman adalah kampung yang terletak di Padukuhan Liman, Kecamatan Kasihan, Bantul bersama Kampung Senggotan dan Tegal Senggotan. Dongkelan Kauman dinyatakan sebagai Kawasan Pathok Negara karena Masjid Pathok Negara Dongkelan berdiri disana [5]. Berangkat dari hal tersebut Setianingrum dkk melakukan pendalaman terhadap kawasan tersebut dan menemukan adanya inti dan identitas Dongkelan Kauman. Selain itu mereka juga mengindikasikan adanya pelapisan-pelapisan ruang di Dongkelan Kauman.

Setianingrum dkk mengemukakan trilogi "masjid, pasareyan-kauman" sebagai inti ruang dan identitas Dongkelan Kauman. Mereka menemukan istilah lokal yang ternyata menjadi identitas Dongkelan Kauman, yaitu pasareyan dan kauman. Pasareyan adalah istilah Jawa dari pemakaman sedangkan kauman adalah perkampungan Muslim tradisional Jawa yang dipimpin oleh seorang Kiai yang diakui oleh Sultan [7].

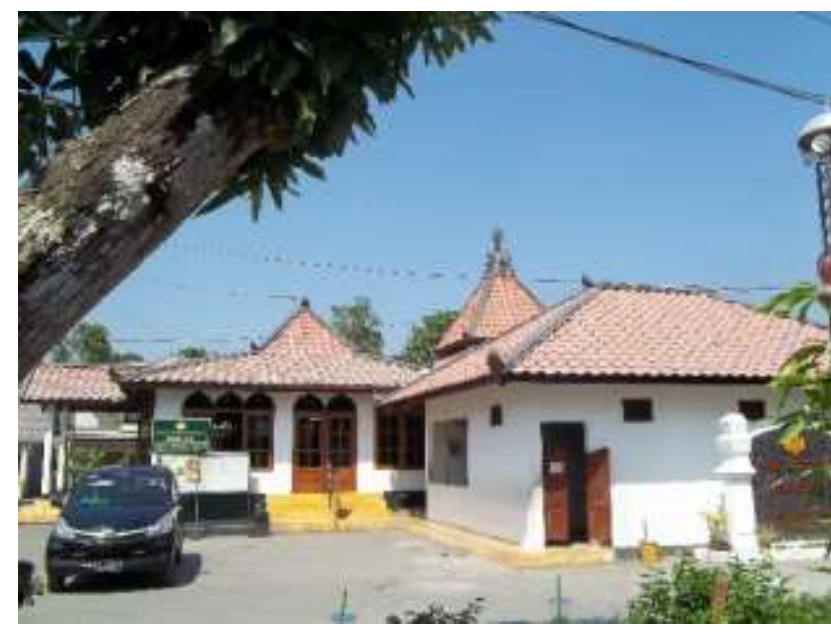

Gambar 2. Masjid Pathok Negara Dongkelan

Ketiga objek ini saling berkaitan satu sama lain. Masjid dan pasareyan harus ada di dalam kauman. Dalam kepercayaan masyarakat tradisional Jawa, pasareyan selalu diletakkan di barat Masjid dengan tujuan mengingatkan jamaah shalat tetang kematian sehingga shalat menjadi lebih khusyuk. Hal ini juga terbaca di Kawasan Pathok Negara Dongkelan [7].

\section{HASIL DAN PEMBAHASAN}

Pelapisan ruang yang diindikasikan Setianingrum dkk ternyata memang ada. Pelapisan ruang di Kawasan Pathok Negara Dongkelan terdiri dari dua tingkatan, yaitu: a) tingkat Dongkelan Kauman; dan c) tingkat padukuhan Liman.

\section{Pelapisan Ruang Dongkelan Kauman}

Pada level ruang Dongkelan Kauman, pelapisan ruang terbentuk dari nilai ruang yang dipengaruhi oleh Masjid Pathok Negara Dongkelan dan pasareyan Dongkelan. Dua objek tersebut merupakan objek paling penting yang terdapat pada Dongkelan Kauman. Keduanya mewujudkan konsep masjid dan pasareyan dalam kauman sebagai inti dan identitas Dongkelan Kauman. Oleh karena itu, berdasarkan pengaruh dari Masjid Pathok Negara Dongkelan dan pasareyan Dongkelan, pelapisan ruang pada level Dongkelan Kauman terdiri dari tiga lapis, yaitu: a) teritori ruang Masjid Pathok Negara Dongkelan; b) radius keunikan Masjid Pathok Negara Dongkelan; dan c) ruang periferi. 
Pelapisan ruang ini terjadi karena adanya nilai-nilai ruang yang masih melekat dalam pikiran masyarakat Dongkelan Kauman.

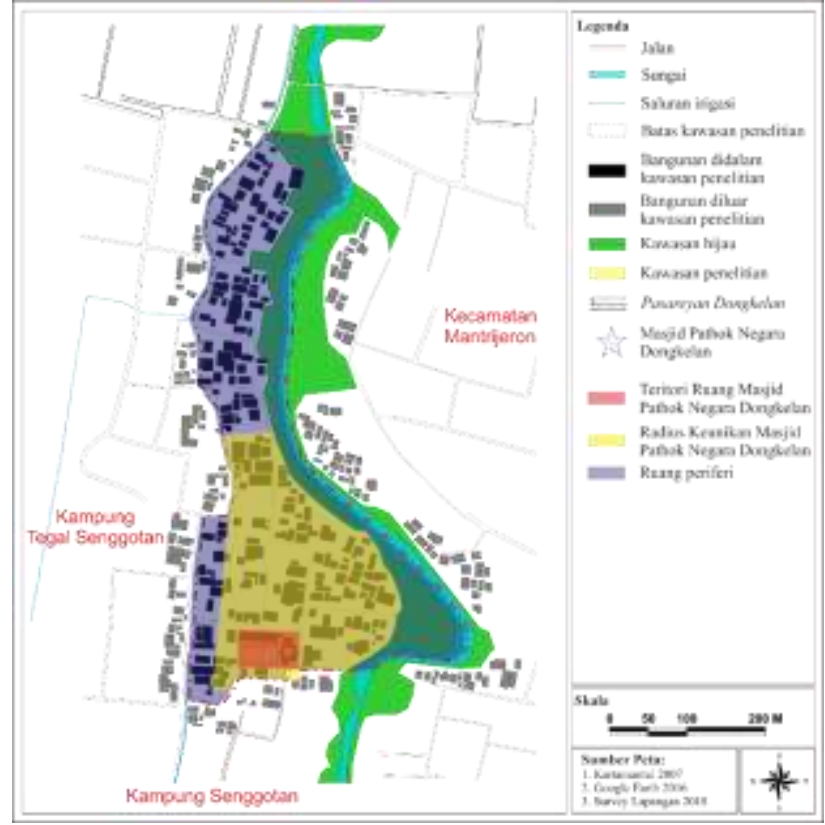

Gambar 3. Pelapisan Ruang Dongkelan Kauman

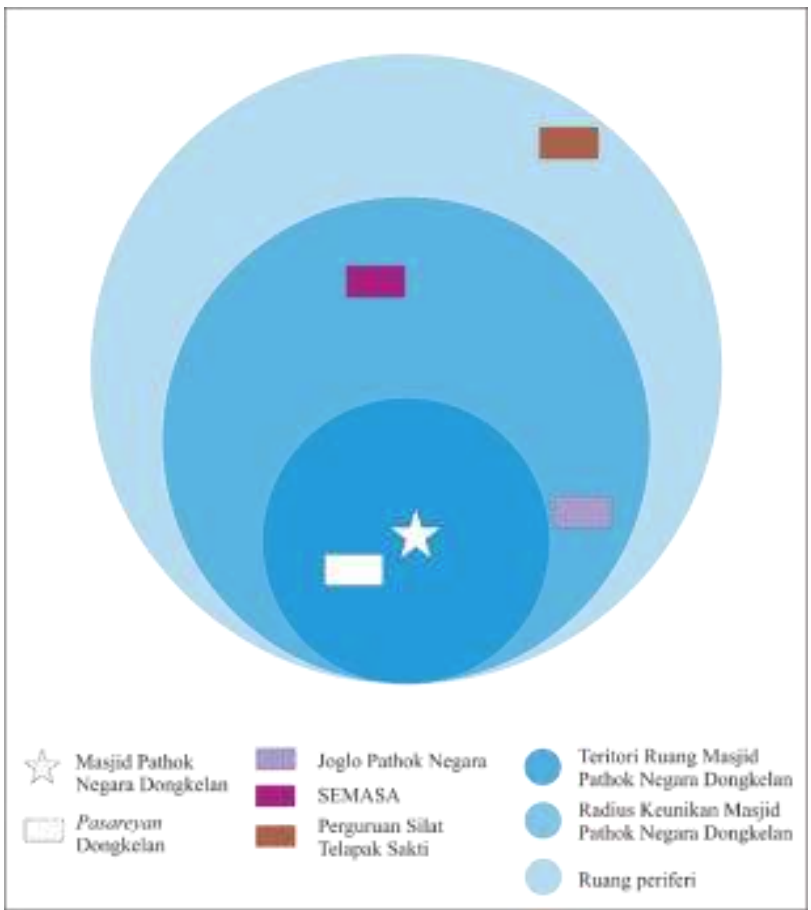

Gambar 4. Abstraksi Pelapisan Ruang Dongkelan Kauman

a. Teritori Ruang Masjid Pathok Negara Dongkelan

Teritori ruang Masjid Pathok Negara Dongkelan adalah ruang yang memungkinkan kekuasaan ruang dari Masjid Pathok Negara Dongkelan dapat dirasakan sepenuhnya. Hal tersebut berarti tidak ada satupun objek yang diizinkan berdiri di area teritori ruang jika objek tersebut mengganggu Masjid Pathok Negara Dongkelan. Pengertian "mengganggu" pada konteks ini adalah merusak nilai sakral maupun nilai sosial dari Masjid Pathok Negara Dongkelan.

Dalam ruang fisik, teritori ruang Masjid Pathok Negara Dongkelan mewujud seluas tanah Kraton yang diberikan kepada Masjid Pathok Negara Dongkelan. Masyarakat Dongkelan Kauman percaya bahwa ruang ini tidak hanya mengandung nilai sakral Masjid melainkan juga nilai sosial dari Masjid Pathok Negara Dongkelan.

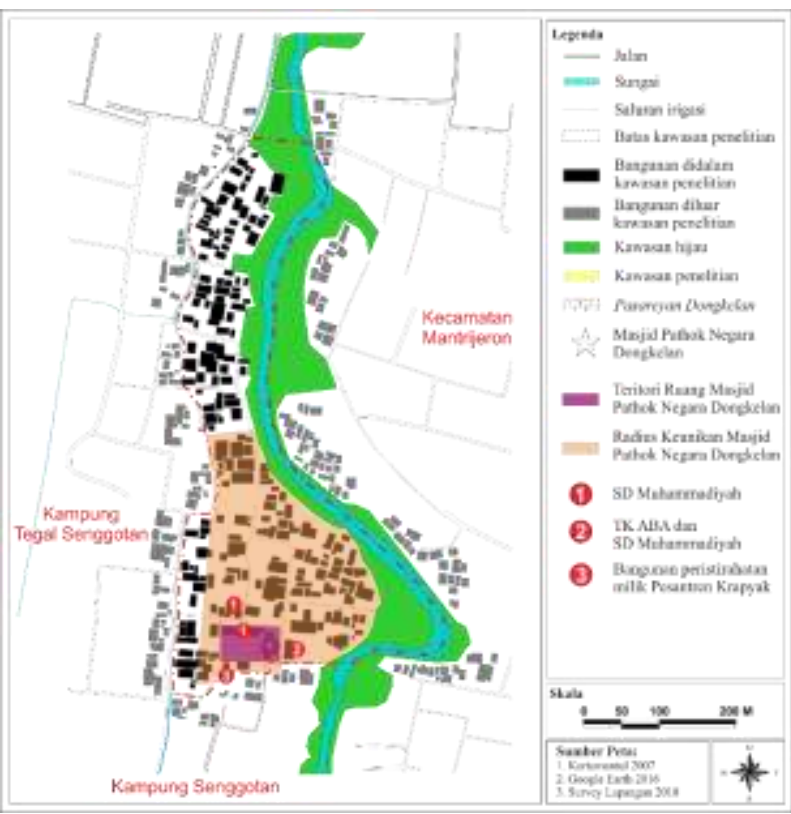

Gambar 5. Teritori Ruang dan Radius Keunikan Masjid Pathok Negara Dongkelan
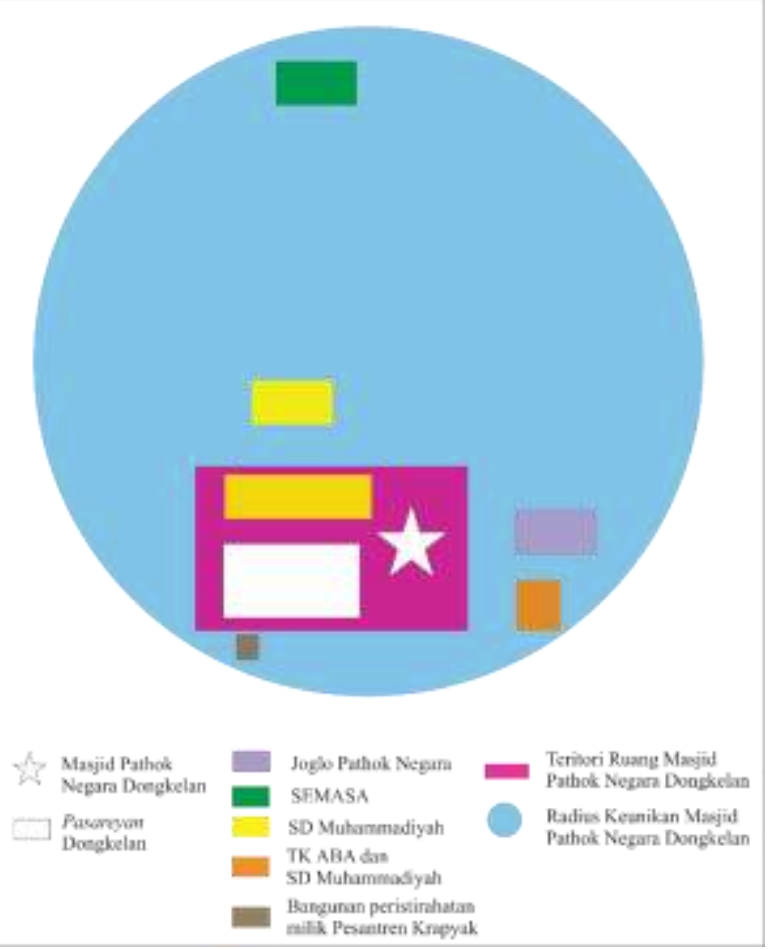

Gambar 6. Abstrak Teritori Ruang dan Radius Keunikan Masjid Pathok Negara Dongkelan

Dari sisi nilai sakral Masjid, masyarakat mempercayai bahwa tidak boleh ada bangunan yang berlantai dua di area teritori ruang ini. Karena Masjid Pathok Negara Dongkelan adalah bangunan 
berlantai satu sehingga shalat pasti dilakukan di lantai satu, masyarakat menganggap bahwa bangunan berlantai dua memungkinkan kegiatan dilakukan di atas orang yang melaksanakan shalat di Masjid. Hal tersebut dianggap tabu dan tidak pantas dilakukan. Oleh karenanya, mendirikan bangunan berlantai dua di teritori ruang Masjid merupakan tindakan yang tidak pantas dilakukan.

Berdasarkan nilai sosial Masjid Pathok Negara Dongkelan, masyarakat sepakat melarang adanya bangunan permanen apapun di halaman Masjid, bahkan taman juga dilarang. Kesepakatan ini terbentuk karena masyarakat menganggap bahwa Masjid Pathok Negara Dongkelan tidak hanya berfungsi sebagai tempat ibadah, melainkan juga tempat masyarakat berinteraksi, meskipun secara arsitektural, ruangan yang dialokasikan untuk kedua fungsi ini dipisahkan dengan ketat. Halaman Masjid adalah tempat yang dialokasikan untuk kegiatan tersebut jika pendopo Masjid tidak bisa menampung peserta kegiatan sosial yang besar. Halaman Masjid biasanya digunakan untuk latihan silat, upacara bendera, hajatan, atau parkir peziarah pasareyan. Masyarakat tidak ingin ada banguan permanen di area teritori Masjid, untuk menghindari hilangnya fungsi-fungsi sosial dari Masjid Pathok Negara Dongkelan ini.

Selain Masjid Pathok Negara Dongkelan, pasareyan juga memiliki nilai sakralnya sendiri. Oleh karena pasareyan terletak tepat di barat Masjid, maka teritori ruangnya bertumpang tindih dengan Masjid Pathok Negara Dongkelan dan lebih tidak teraba. Dalam konteks nilai sakral dan teritori ruang pasareyan, masyarakat melarang adanya bangunan yang bersifat keduniaan dibangun di dekat pasareyan, agar kesakralan pasareyan sebagai pengingat kematian dan akhirat tidak memudar.

\section{b. Radius Keunikan Masjid Pathok Negara Dongkelan \\ Radius keunikan Masjid Pathok Negara} Dongkelan dideskripsikan sebagai ruang tertentu yang masih dipengaruhi kharisma dari Masjid Pathok Negara Dongkelan. Radius keunikan merupakan perluasan dari teritori ruang Masjid. Kharisma Masjid Pathok Negara Dongkelan mempengaruhi keputusan masyarakat dalam membangun di ruang radius keunikan tersebut. Hal ini menyebabkan ada ruang spesifik meskipun tidak memiliki batas rigid, namun perbedaannya terasa dibandingkan ruang yang lain.

Radius keunikan Masjid Pathok Negara Dongkelan mewujud dalam ruang yang dimulai dari batas teritori ruang Masjid Pathok Negara Dongkelan meluas sekitar 200 meter ke utara atau sampai perbatasan RT 6 dan RT 5 Dongkelan Kauman. Pada ruang ini masyarakat menyepakati bahwa tidak diizinkan membangun bangunan berlantai dua. Kesepakatan tersebut didasari kepercayaan bahwa bangunan di sekitar masjid tidak boleh melebihi tinggi masjid. Masyarakat lokal masih mempercayai falsafah lama yang menyebutkan bahwa jika seseorang memiliki rumah disekitar masjid, maka tidak pantas memperbaiki rumah sebelum masjidnya terlihat bagus. Deskripsi tersebut menunjukkan bahwa kharisma Masjid Pathok Negara Dongkelan sebagai objek yang harus dihormati masih terasa melampaui teritori ruangnya, sehingga pada akhirnya ruang, yang menggambarkan radius keunikan, ini terbentuk.

Radius keunikan Masjid Pathok Negara Dongkelan ini menunjukkan fenomena yang unik pula. Jika yang terbayangkan dengan radius adalah buffer lingkaran sempurna dengan komposisi yang seimbang (objek unik ada di pusat lingkaran), maka radius keunikan Masjid Pathok Negara Dongkelan tidak memiliki komposisi yang sempurna (gambar 6). Lingkaran radius keunikan condong ke utara dengan Masjid Pathok Negara Dongkelan berada di batas paling selatan. Keunikan ini disebabkan karena Masjid Pathok Negara Dongkelan merupakan batas paling selatan dari Dongkelan Kauman, sehingga ruang di selatan Dongkelan Kauman merasa tidak perlu mengikuti kesepakatan ruang tentang pembatasan tinggi bangunan.

\section{c. Ruang periferi}

Ruang periferi adalah ruang yang tidak lagi dipengaruhi oleh kharisma Masjid Pathok Negara Dongkelan. Ruang ini adalah batas terluar Dongkelan Kauman. Pada ruang ini tidak terasa kharisma Masjid Pathok Negara Dongkelan yang mempengaruhi ketinggian bangunan. Kesepakatan tentang pembatasan ketinggian bangunan tidak lagi diterapkan. Hal ini ditunjukkan dengan banyaknya bangunan berlantai dua di ruang periferi. Kharisma Masjid Pathok Negara Dongkelan tidak dirasakan dengan adanya Mushola lain di ruang ini sebagai pusat kegiatan keagamaan masyarakat uang tinggal pada ruang ini.

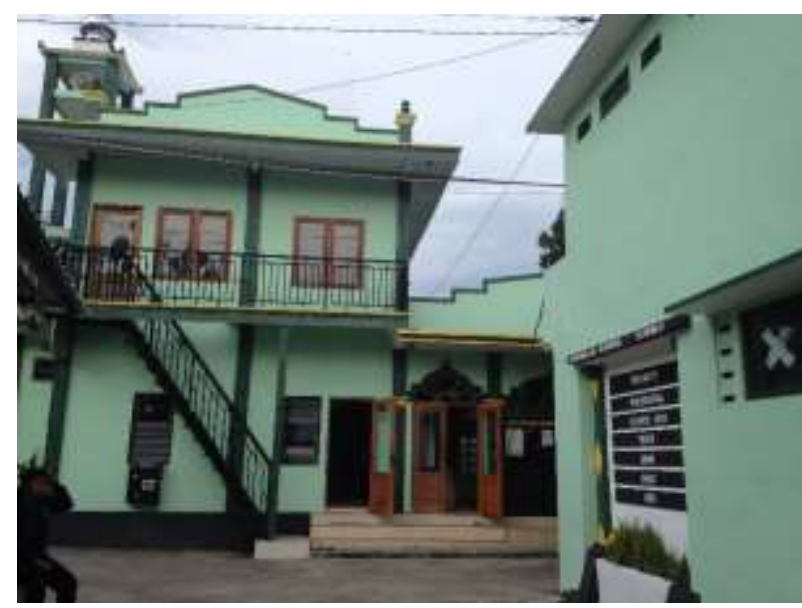

Gambar 7. Mushola di Ruang Periferi sebagai Bukti Kharisma Masjid Pathok Negara Dongkelan Tidak Mempengaruhi Ruang Periferi 


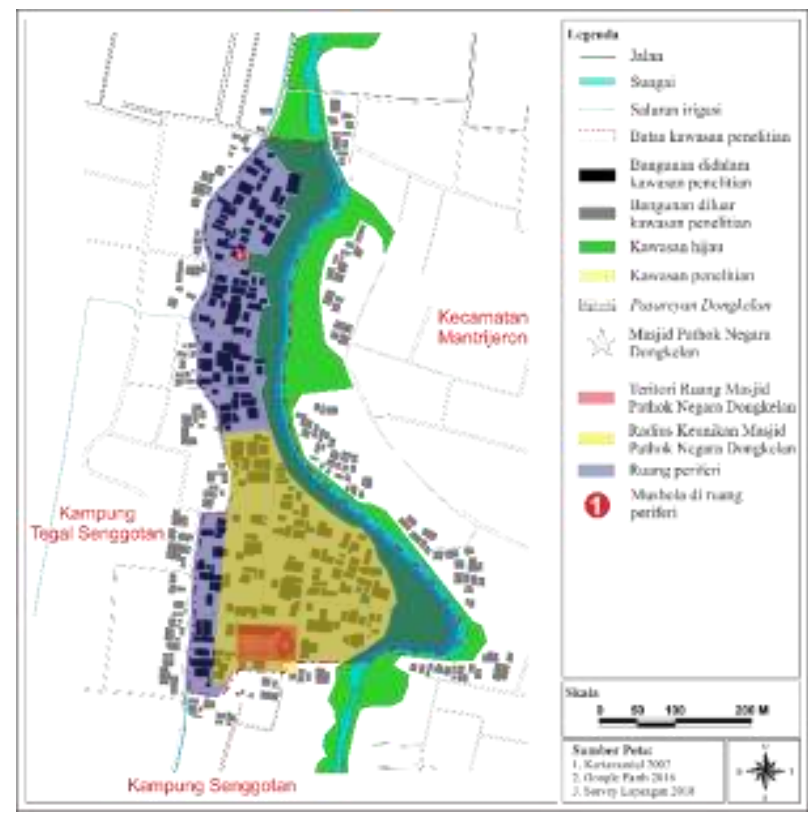

Gambar 8. Letak Mushola di Ruang Periferi

d. Anomali pada Teritori Ruang dan Radius Keunikan Masjid Pathok Negara Dongkelan

Telah dijabarkan di bagian sebelumnya bahwa radius keunikan merupakan perluasan dari teritori ruang. Hal tersebut berarti bila sebuah objek memiliki radius keunikan, maka objek tersebut pasti memiliki teritori ruang. Fenomena berbeda terjadi pada Masjid Pathok Negara Dongkelan.

Masjid Pathok Negara Dongkelan tidak lagi memiliki teritori ruang tetapi masih memiliki radius keunikan. Anomali ini disebabkan oleh adanya bangunan permanen berlantai dua yang melangkahi nilai sakral Masjid Pathok Negara Dongkelan dan pasareyan Dongkelan (gambar 6). Bangunan tersebut bukan merupakan bangunan yang didirikan oleh penduduk lokal tetapi oleh institusi lain diluar Dongkelan Kauman.

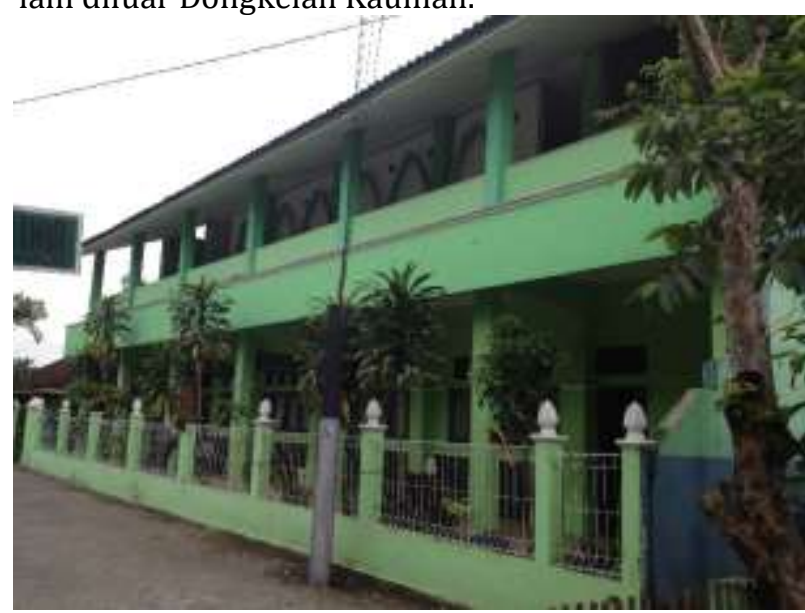

Gambar 9. Bangunan Berlantai Dua di Utara Masjid Pathok Negara Dongkelan yang Mengikis Teritori Ruang Masjid Pathok Negara Dongkelan

Menurut penduduk, kedua bangunan tidak didirikan bersamaan. Banguan yang pertama didirikan sebenarnya telah meminta izin untuk membangun dua lintai dan tidak diizinkan, namun mereka bersikeras membangunnya. Warga merasa kecewa dan melaporkannya pada pihak Kraton Yogyakarta, yang memiliki kewenangan terhadap Kawasan Pathok Negara.

Sebagai respon atas laporan tersebut, pihak Kraton justru mengizinkan bangunan yang sudah terlanjur didirikan tersebut karena bangunan itu merupakan bangunan sekolah, yang dianggap merupakan bangunan bernilai sosial kemasyarakatan. Pada akhirnya ada akibat lanjutan dari keputusan tersebut. Ada bangunan berlantai dua lain yang dibangun di teritori ruang pasareyan Dongkelan. Bangunan berlantai dua kedua dibangun di teritori ruang pasareyan Dongkelan merupakan bangunan peristirahatan. Keberadaan bangunan yang bersifat keduniaan ini mengurangi nilai sakral pasareyan yang bernilai akhirat.

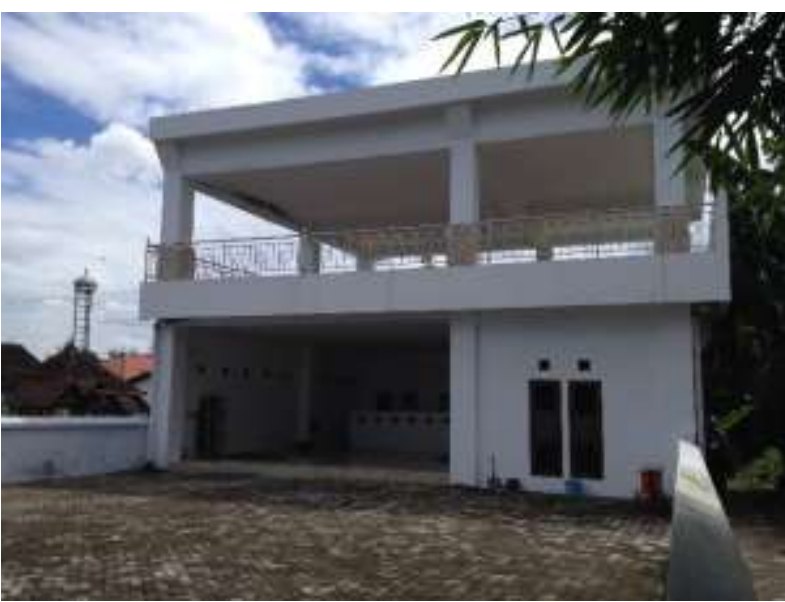

Gambar 10. Bangunan Berlantai Dua di Utara Masjid Pathok Negara Dongkelan yang Mengikis Teritori Ruang pasareyan Dongkelan

Dalam konteks ini, sebenarnya Masjid Pathok Negara Dongkelan pada awalnya memiliki teritori ruang. Berdirinya kedua bangunan tersebut di menyebabkan terkikisnya teritori ruang Masjid Pathok Negara Dongkelan. Meskipun teritori ruangnya telah terkikis, Masjid Pathok Negara Dongkelan masih memiliki radius keunikan yang tetap terjaga. Hal ini ditunjukkan dengan adanya kesepakatan pemba-tasan tinggi bangunan pada radius tertentu dari Masjid yang tetap dipegang kuat oleh masyarakat Dongkelan Kauman.

\section{Pelapisan Ruang Padukuhan Liman}

Selain terbentuk pada level kampung, pelapisan ruang juga terbentuk pada level padukuhan. Dalam masyarakat Yogyakarta, padukuhan merupakan gabungan dari kampung-kampung. Kampung merupakan wilayah yang terdiri dari beberapa RT yang pembagian wilayah berdasarkan kesepakatan serta tidak memiliki kepala administrasi, sedangkan padukuhan memiliki seorang kepala dukuh.

Pelapisan ruang pada level padukuhan terjadi akibat adanya persamaan sejarah tetapi mengalami perbedaan kondisi empiris. Berdasarkan sejarahnya, 
ketiga kampung di Padukuhan Liman merupakan tanah yang diberikan kepada Pejabat Pathok Negara Pertama dari Dongkelan (Kiai Syihabuddin). Pada perjalanannya, wilayah tersebut terpecah menjadi tiga kampung. Hanya Dongkelan Kauman mempertahankan identitasnya sebagai perkampungan Muslim dan menjaga peninggalan-peninggalan Kiai Syihabuddin. Oleh karena itu, saat ini dari ketiga kampung tersebut, hanya Dongkelan Kauman yang memakai nama kauman, yang berarti perkampungan Muslim dalam Bahasa Jawa.

Sampai saat ini, masyarakat Dongkelan Kauman bersepakat menghindari adanya penduduk non-Muslim di Dongkelan Kauman. Mereka melakukan hal tersebut untuk mempertahankan sejarah kampungnya dan menghindari perasaan asing sang warga non-Muslim karena tinggal di lingkungan yang berbeda. Berbeda dengan Dongkelan Kauman yang tetap mempertahankan identitasnya sebagai perkampungan Muslim sejak tahun 1775, Kampung Senggotan dan Tegal Senggotan tidak melakukannya.

Selain keputusan masyarakat untuk mempertahankan identitas kampungnya, objek-objek penting yang berhubungan dengan Pathok Negara, seperti Masjid Pathok Negara Dongkelan, pasareyan Dongkelan, perguruan silat Telapak Sakti, dan Joglo Pejabat Pathok Negara terakhir, berada di Dongkelan Kauman. Keberadaan objek-objek tersebutlah yang memperkuat semangat warga Dongkelan Kauman untuk mempertahankan bukti sejarah tempat tinggalnya. Semangat memepertahankan bukti sejarah ini tidak terlalu terasa di Kampung Senggotan dan Tegal Senggotan.

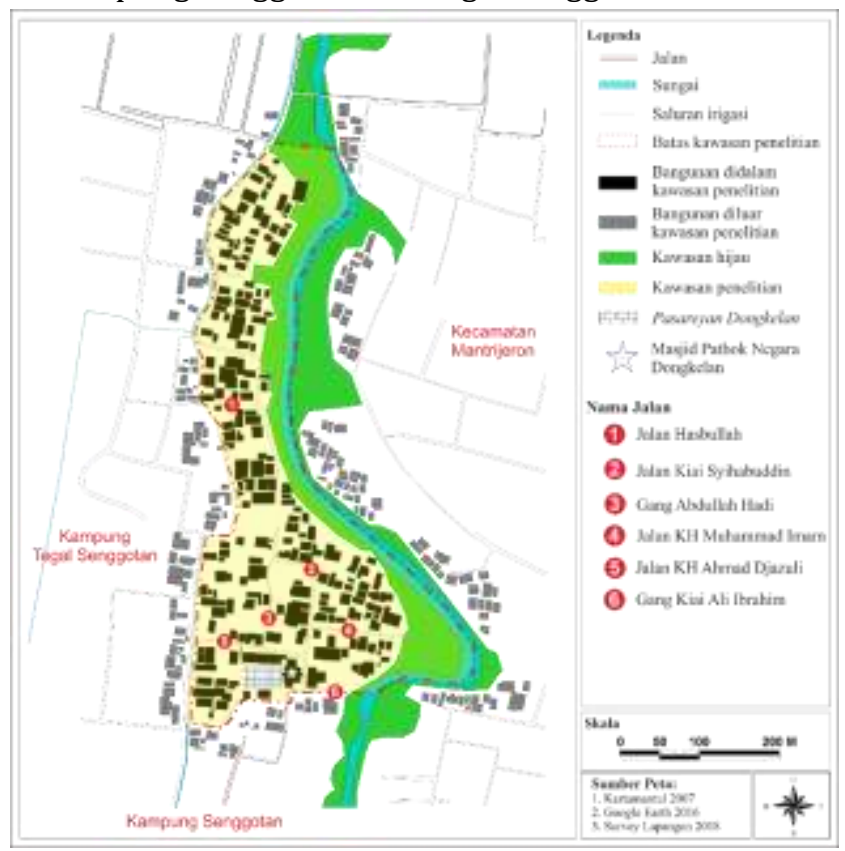

Gambar 11. Peta Jalan Dongkelan Kauman

Usaha lain masyarakat untuk memperkuat keterikatan Dongkelan Kauman dengan sosok Kiai Syihabuddin adalah menamai jalan dan gang di Dongkelan Kauman dengan nama Kiai Syihabuddin dan keturunannya. Hal ini juga dilakukan untuk meng- ingatkan generasi mendatang akan akar sejarah Dongkelan Kauman. Usaha-usaha tersebut tidak dilakukan oleh Kampung Senggotan dan Tegal Senggotan.

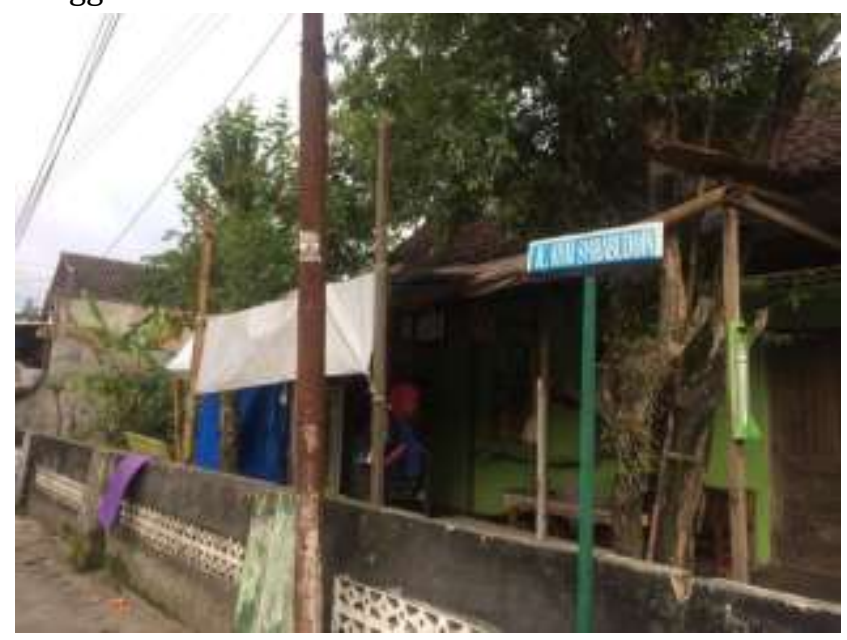

Gambar 12. Contoh Papan Nama Jalan di Dongkelan Kauman

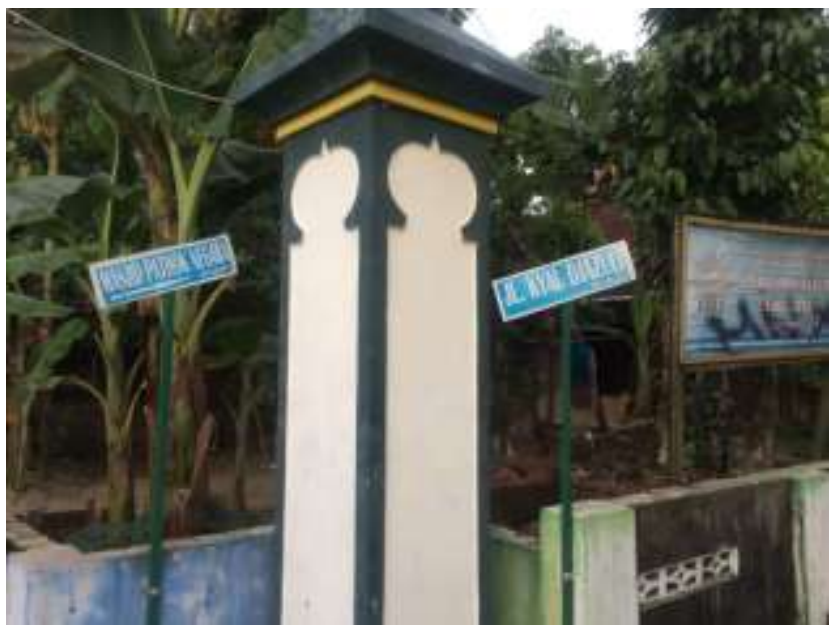

Gambar 13. Contoh Papan Nama Jalan di Dongkelan Kauman

Kedua hal tersebutlah yang membuat Padukuhan Liman memiliki dua lapisan, yaitu: a) ruang inti, meliputi Dongkelan Kauman; dan b) ruang periferi, yang terdiri dari Kampung Senggotan dan Tegal Senggotan (gambar 10). Abstrak ruang inti dan ruang periferi (gambar 11) pada level Padukuhan Liman juga tidak menujukkan inti di pusat lingkaran. Hal ini dikarenakan daerah di timur sungai tidak memiliki keterikatan sejarah daengan Padukuhan Liman dalam konteks sejarah Pathok Negara. 


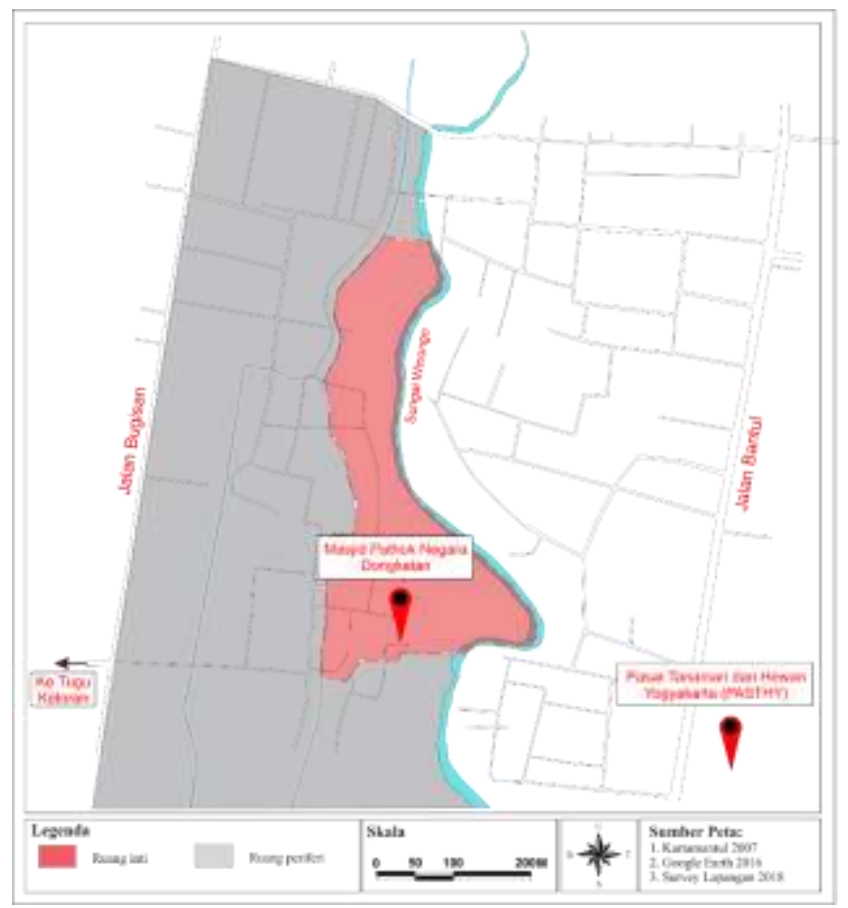

Gambar 11. Pelapisan Ruang Padukuhan Liman

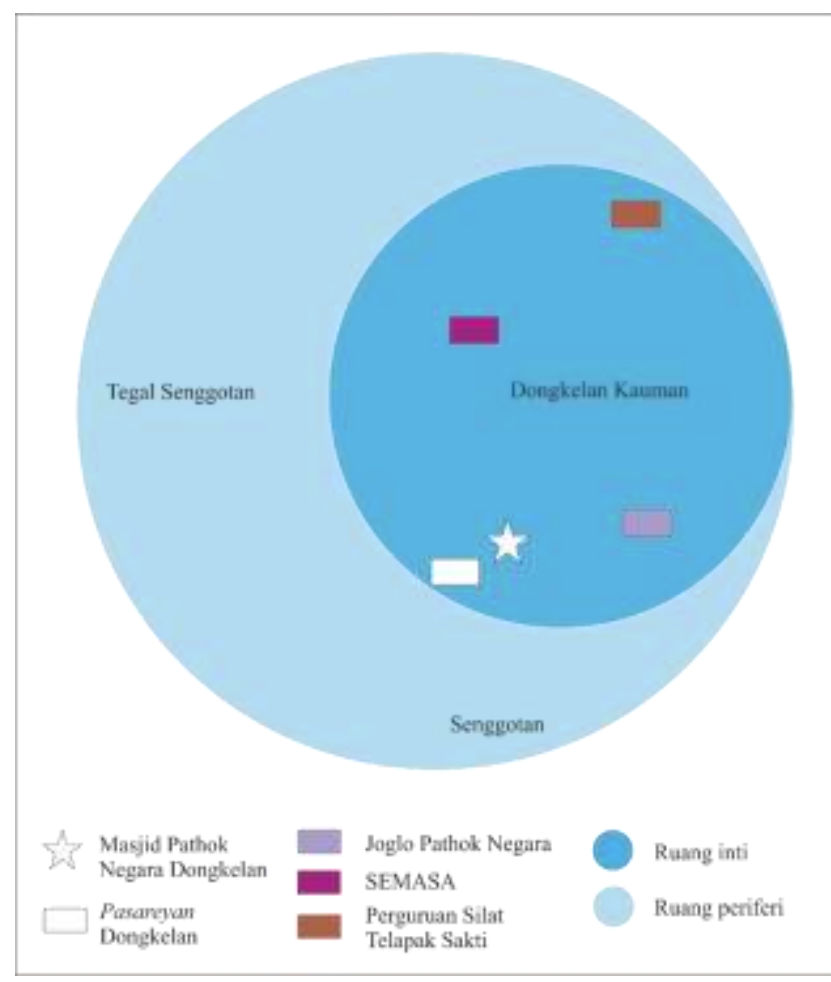

Gambar 12. Abstraksi Pelapisan Ruang Padukuhan Liman

\section{TEMUAN ATAU DISKUSI (JIKA ADA)}

Temuan paper ini mendetailkan konsep trilogi inti dan identitas Dongkelan Kauman oleh Setianingrum dkk. Pernyataannya mengenai indikasi adanya pelapisan ruang yang disebabkan oleh inti ruang semakin diperdalam. Ternyata yang berperan sebagai pembentuk pelapisan ruang bukanlah keputusan penggunaan ruang yang terpengaruh oleh objek unik, melainkan nilai-nilai ruang yang terbentuk akibat adanya keputusan tersebut. Paper ini mengabstraksi lebih jauh mengenai pembentuk pelapisan ruang yang diindikasikan oleh Setianingrum dkk.
Selain itu, konsep nilai ruang sebagai pembentuk pelapisan ruang juga memperkuat konsep Rahmi dan Sudaryono. Konsep Rahmi yang mengajukan Kawasan Pathok Negara sebagai cultural heritage semakin diperkuat oleh bukti bahwa keunikan Dongkelan Kauman sebagai Kawasan Pathok Negara tidak hanya berupa keberadaan Masjid Pathok Negaranya saja, melainkan juga terwujud pada sistem keruangannya yang dipengaruhi nilai ruang yang tertanam dalam pikiran masyarakatnya.

Konsep eksistensi spasial dan radius keunikan oleh Sudaryono juga diperkuat oleh temuan paper ini. Masyarakat, objek unik, dan sistem nilai merupakan pilar yang saling berkaitan. Keterkaitan ketiganya mampu membentuk sebuah sistem keruangan yang unik pula. Dalam konteks radius keunikan, ternyata sebuah kharisma dan nilai yang dikandung oleh sebuah objek unik mampu mempengaruhi keputusan penggunaan ruang masyarakat, membentuk sistem nilai yang spesifik, dan membentuk sistem keruangan yang unik.

\section{E. SIMPULAN DAN SARAN}

Objek yang mengalami kemenerusan dalan sebuah ruang tidak serta-merta hilang pengaruhnya. Ternyata objek tersebut tetap dapat mempengaruhi keputusankeputusan masyarakat dalam memanfaatkan ruangnya dan membentuk nilai-nilai ruang yang spesifik. Objek unik dan penghormatan masyarakat terhadapnya merupakan sesuatu yang berhubungan timbal balik. Jika salah satu diantara keduanya dihilangkan maka sistem ruang yang spesifik, seperti yang terbentuk di Kawasan Pathok Negara Dongkelan, juga akan memudar.

\section{UCAPAN TERIMA KASIH}

Penulis utama memberikan penghormatan setinggitingginya kepada Profesor Sudaryono dan Dr. Sani untuk waktu dan bimbingan yang telah diberikan kepada penulis utama saat menyelesaikan penelitian untuk penulisan paper ini.

\section{DAFTAR RUJUKAN}

[1] Lynch, K., What Time Is This Place?, MIT Press, Cambridge, 1972.

[2] Rossi, A., The Architecture of The City, MIT Press, Cambridge, 1984.

[3] Jo, A., "Aldo Rossi: Architecture and Memory", Journal of Asian Architecture and Building Engineering, Vol 2, No. 1, h. 231-237, May 2003.

[4] Sudaryono., "Paradigma Lokalisme Dalam Perencanaan Spasial", Jurnal Perencanaan Wilayah Dan Kota, Vol 17, No. 1, h. 28-38, Desember 2006.

[5] Bappeda DIY, Naskah Akademik Babon Peraturan Daerah Istimewa DIY. Bappeda DIY, Yogyakarta, 2013. 
90 | Jurnal Planoearth | Vol. 3, No. 2, Agustus 2018, hal 83-90

[6] Rahmi, D., Pathok Negara Yogyakarta as a Cultural Landscape. Prosiding 3th Biennale ICIAP (International Conference on Indonesian Architecture and Planning); Inclusive Space, Enriching Culture, Yogyakarta, Indonesia, h. 356-361, Agustus 2016.

[7] Setianingrum, L., Sudaryono., Roychansyah, M.S., Trilogy of "Masjid, Pasareyan, and Kauman" as Spatial Core and Identity of Dongkelan Kauman Settlements. Prosiding 4th Biennale ICIAP (International Conference on Indonesian Architecture and Planning); Design and Planning in The Disruptive Era, Yogyakarta, Indonesia, h. 331-339, Juli 2018. 